\title{
Exploring the Interaction Factors Effecting the Student Retention in Online Courses
}

\author{
Yuan Yuan \\ Harbin Institute of Technology (Shenzhen) \\ Shenzhen, China
}

\author{
Xi Cun* \\ School of Humanities and Social Sciences \\ Harbin Institute of Technology (Shenzhen), \\ Shenzhen, China \\ *Correspondence Author
}

\begin{abstract}
In the era of "digital native", massive open online courses (MOOCs) have shared a lot of educational resources. However, MOOC is deeply troubled by low retention rates. Therefore, this study focuses on the analysis of factors which influence the perceived effectiveness and satisfaction in MOOC, including instructor-student interaction, student-student interaction, and student-content interaction. It aims to provide solution to improve the retention of MOOC.
\end{abstract}

Keywords-MOOC retention; interaction; perceived effectiveness; satisfaction

\section{INTRODUCTION}

In the "digital native" era [1], great changes have taken place in distance education. Massive open online courses (MOOCs) as a new way of education have been popular with teachers and students in all colleges and universities around the world, which makes the high-quality educational resources to be available globally. So MOOC has attracted more and more attention. Compared to traditional curricula, MOOCs have large scale, surpassing geographical and social constraints, and achieving broad and free personal involvement, which have a revolutionary impact on global education. MOOC provides students with a wealth of curriculum options, covering a wide range of disciplines such as Humanities and Social Sciences, Computer Science, Physics, Engineering, and Mathematics. There are dozens of famous universities around the world, which have opened a large number of courses and attracted students from all over the world. In particular, the Moocs of the Harvard University, Stanford University and other well-known universities are open to thousands of learners, causing extensive social discussion.

Although early MOOC was developed based on user connections [2], teacher-driven MOOCs dominate online learning today. As the result of the free opening of many curriculum resources, students and other learners who are unable to receive higher education can obtain high quality educational resources through the Internet. [3]. Compared with the high cost of face-to-face education at the top universities in the west, MOOC will bring considerable potential benefits to the students in the vast developing countries and regions [4]. But at present, the educational level of MOOC users is high, mostly from developed countries and most of them are men. Developing countries and regions such as Africa and Asia have relatively low retention rates of $\mathrm{MOOC}$, ranging from $5 \%$ to $15 \%$ despite having a large population with lower education levels [5].

Some scholars have carried out research on the causes of the low rate retention MOOC, but most are single case study [6], or the analysis of the learning intention, lack of research on the behavior of MOOC in the process of learning [7], such as interaction function of online courses. Interaction of online courses [8] is divided into three important interactions instructor-student interaction, student-student interaction and student-content interaction. Eom, et al. [9] believed that these three forms of interaction play an important role in determining the quality of online courses. Peltier et al. [10] studied 299 online MBA course learners and found that instructor-student interaction and teacher support have an impact on curriculum perceived effectiveness. After researching the online learning behaviors of 397 American college students, Eom et al. [9] found that teacher feedback influenced student satisfaction. Good perceived effectiveness contributes to student retention [4] However, these studies mostly focus on teacher behavior research, less on other aspects of interaction research, and mostly on developed countries. There is little research on online curriculum interaction in developing countries.

So, the research will be carried out from the following aspects. First, it is going to analyze the three types of interaction which are instructor-student interaction, studentstudent interaction, student-content interaction in MOOCs, and study the influence of these factors on perceived effectiveness and learner satisfaction. It will mainly collect data of MOOCs in China to fill the research gap lack of research in developing countries. Then, it will study the impact of perceived effectiveness on learner satisfaction, and explore the mediating effect of perceived effectiveness and student satisfaction on antecedent variables and student retention. The rest of the paper is organized as follow: The second part is a literature review and assumptions about the interaction between perceived effectiveness, student satisfaction, and student retention. The third part is methodoly, which includes measurements, samples and data. The fourth part is the research results. In the last section it will the limitations of the research. 
This template, modified in MS Word 2007 and saved as a "Word 97-2003 Document" for the PC, provides authors with most of the formatting specifications needed for preparing electronic versions of their papers. All standard paper components have been specified for three reasons: (1) ease of use when formatting individual papers, (2) automatic compliance to electronic requirements that facilitate the concurrent or later production of electronic products, and (3) conformity of style throughout a conference proceeding. Margins, column widths, line spacing, and type styles are built-in; examples of the type styles are provided throughout this document and are identified in italic type, within parentheses, following the example. Some components, such as multi-leveled equations, graphics, and tables are not prescribed, although the various table text styles are provided. The formatter will need to create these components, incorporating the applicable criteria that follow.

\section{LITERATURE REVIEW AND HYPOTHESES}

The literature review includes the following topics: (a) instructor-student interaction in MOOCs (b), student-student interaction in MOOCs (c) student-content interaction (d), perceived effectiveness and satisfaction of students as shown in "Fig. 1".

\section{A. Instructor-student Interaction in MOOCs}

Swan [11] considers that effective interaction between instructors and students will help to achieve a higher degree of learning satisfaction. In addition, the level of interaction between students is also positively correlated with learning satisfaction and learning outcomes. The opinion of online course interaction can be roughly divided into two groups; the pessimists thought that distance education were lack of face-to-face interaction; but optimists believed that the instruct-student interaction of distance education is not worse than traditional education $[12,13]$. Similar to online classes, in traditional education environments, students spend most of their time outside of class only 1-2 hours per day to study in class [14]. Although online teaching had many difficulties in delivering non-verbal messages (including emotions), and nonverbal messages can be delivered through texts and emoji [15]. In terms of direct language communication (Gorham, 1988), it is still possible to do it online. But, teachers can solve problems of students and provide feedback by emails and social media discussions. Direct oral language in the online teaching environment can be well expressed [16, 17]. Therefore, the hypotheses are as following:

- H1a.Instructor-student interaction in MOOCs will have a positive impact on perceived effectiveness.

- H2b. Instructor- student interaction in MOOCs will have a positive impact on student satisfaction.

\section{B. Student-student Interaction in MOOCs}

Such as instructor-student interaction is an important factor affecting the retention of MOOCS, student-student interaction (such as group discussion and peer teaching) is also important. In the online courses, teachers preferred peer learning through group discussions and team projects, which is different from traditional education [18]. Among them, the virtual community played an important role. In the absence of any consideration in the face-to-face tutorials, students could speak freely and increase their emotional connections with their peers in the forum [19]. Hagel and Armstrong [20] also considered that virtual community that transcends geographic and temporal constraints would play an important role in building intimate relationships between students, just like business virtual communities. The size and structure of the learning group is also critical as the virtual community takes on the task of team and group discussion [10]. Speeches of students in the forum were positively responded, which enhanced their enthusiasm for learning and participate more actively in classroom participation, so as to achieve objective learning results. [21]. It had been found that there is a significant relationship student-student interaction and perceived effectiveness $[10,14]$. A small group of curriculum discussions would enhance social existence and the satisfaction of online courses and forums [22]. It was found online courses are freer than traditional teaching [23]. Participation in class discussions and positive interaction among students helped to improve user stickiness [16, 24], but were more difficult to achieve [25]. Therefore, the impact of student-student interaction in MOOCs on student perceived effectiveness and course satisfaction deserves study.

- H2a. Student-student interaction in MOOCs will have a positive impact on perceived effectiveness.

- H2b. Student-student interaction in MOOCs will have a positive impact on student satisfaction.

\section{Student-content Interaction in MOOCs}

Student content interaction refers to using PowerPoint presentation, streaming audio and video demo, group projects, and hyperlinks to conduct network teaching and homework. [26]. It is noteworthy that the excessive use of these teaching tools may cause perception disorders. Because of the lack of non-verbal communication and unmodified text media, teachers could not just copy the traditional classroom environment in the online classroom [14]. Online courses could enhance sensory experience of students with the help of multimedia technology, such as voice and video clips [27]. The instructor-delivered content [28], internet driven content [29], and assigned learning and assessment activities [30] all might affect the perceived effectiveness of students. If students gained valuable course content in online courses, they would be more actively engaged in community discussions, enhancing contact among students and achieving good learning outcomes. [31]. The content of high quality curriculum was often inspected from many aspects, including the evaluation of the test, homework, project and the teacher's behavior, the difficulty of the course and so on [32]. Curriculum design, quality and related assessment had been studied [33]. Peltier et al. [34] found that the content of the curriculum was one of the most important factors affecting the perception effectiveness through surveying online MBA students. In MOOCs, course content (CC) is also an important factor affecting the perception effectiveness [4]. Based on this, we assume: 
- H3a.Student-content interaction in MOOCs will have a positive impact on perceived effectiveness.

- H3b. Student-content interaction in MOOCs will have a positive impact on student satisfaction.

\section{Perceived Effectiveness and Student Satisfaction}

The MOOC retention is the focus of the research. In online courses, perception effectiveness and satisfaction of students are closely related to the course content, curriculum structure, interaction and other [14]. The perceived effectiveness and the student satisfaction are important indicators to measure MOOC retention. Therefore, we speculate:

- H4. Perceived effectiveness of MOOCs will have a positive impact on Student satisfaction.

- H5a. Perceived effectiveness of MOOCs will have a positive impact on learner retention.

- H5b. Student satisfaction of MOOCs will have a positive impact on learner retention.

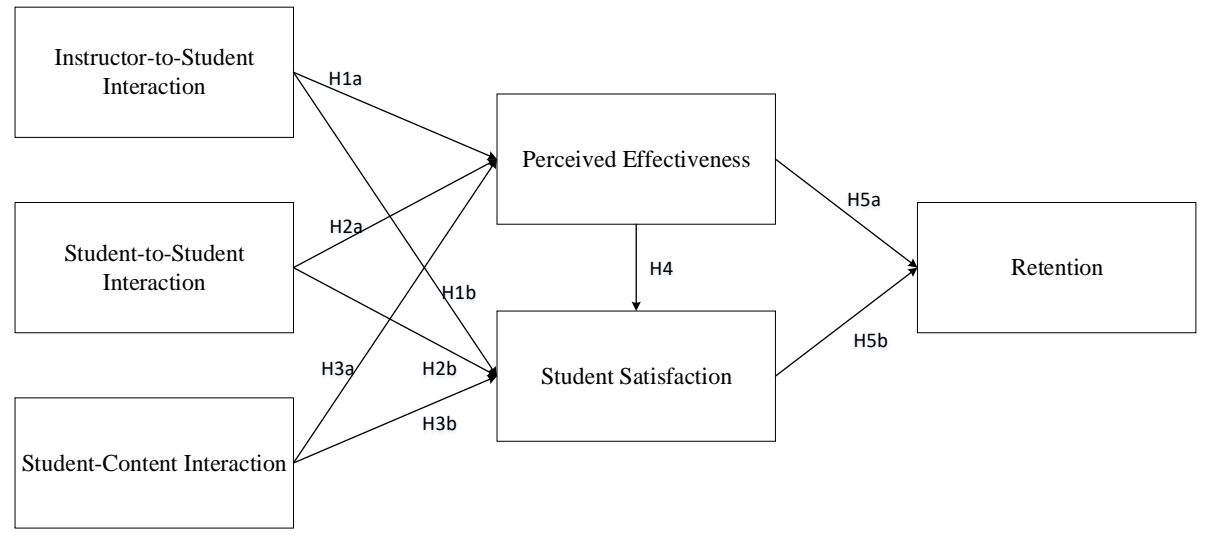

Fig. 1. Conceptual model.

\section{METHODS}

A university in China will be chosen to carry out the study on the retention of MOOCs courses. Data will be collected by sending questionnaires to students who have attended at least one online course, in order to verify the five sets of hypotheses mentioned above. In addition to collecting the basic personal information of the respondents, the questionnaire includes questions about instructor-student interaction, student-student interaction, student-content interaction, curriculum contents, perceived effectiveness, curriculum satisfaction and student retention. The questionnaire provides open text answers to questions about the reason why the respondents did not complete the course. The structural equation model will be used to verify the determinants of the perceived effectiveness and the curriculum satisfaction in online courses.

\section{CONCLUSION}

With the help of information transmission technology, MOOC transcended geographical and social boundaries, and provides a wide range of educational resources for students from all over the world, which has been well received by teachers and students. In particular, MOOC provided an objective potential benefit for developing countries and regions with backward educational resources. However, MOOC is deeply troubled by low retention rates, which has challenged the large-scale promotion of online courses.

This paper will study student perceived effectiveness and the satisfaction metrics that affected the retention of MOOCs and will analyze the important interactions that affect these metrics, namely, instructor-student interaction, studentstudent interaction, student-content interaction. However, we only focus on the analysis of the interaction of these factors, without considering the other factors and the interaction function between these factors.

\section{REFERENCES}

[1] J. Palfrey and U. Gasser, "Born Digital: Understanding the First Generation of Digital Natives," World Future Review, vol. 4, pp. 6667, 2008.

[2] R. Mcgreal, W. Kinuthia and S. Marshall, "Massive Open Online Courses: Innovation in education?" Austcolled.com.au, 2013.

[3] F. M. Hollands and D. Tirthali, "MOOCs: Expectations and Reality. Full Report.," Online Submission, 2014.

[4] K. S. Hone and G. R. E. Said, "Exploring the factors affecting MOOC retention: A survey study," Computers \& Education, vol. 98, pp. 157168,2016

[5] T. R. A. A. Liyanagunawardena, "MOOCs: A Systematic Study of the Published Literature 2008-2012.," International Review of Research in Open \& Distance Learning, vol. 14, pp. 202-227, 2013.

[6] J. A. Greene, C. A. Oswald and J. Pomerantz, "Predictors of Retention and Achievement in a Massive Open Online Course.," American Educational Research Journal, vol. 52, 2015.

[7] K. M. Alraimi, H. Zo and A. P. Ciganek, "Understanding the MOOCs continuance: The role of openness and reputation," Computers \& Education, vol. 80, pp. 28-38, 2015.

[8] P. T. Northrup, "Online Learners' Preferences for Interaction.," Quarterly Review of Distance Education, vol. 3, 2002.

[9] S. B. Eom, H. J. Wen and N. Ashill, "The Determinants of Students' Perceived Learning Outcomes and Satisfaction in University Online Education: An Empirical Investigation," Decision Sciences Journal of Innovative Education, vol. 4, pp. 215-235, 2006. 
[10] J. W. Peltier, W. Drago and J. A. Schibrowsky, "Virtual Communities and the Assessment of Online Marketing Education," Journal of Marketing Education, vol. 25, pp. 260-276, 2003.

[11] K. Swan, "Virtual interaction: Design factors affecting student satisfaction and perceived learning in asynchronous online courses," Distance Education, vol. 22, pp. 306-331, 2001.

[12] K. Swan, "LEARNING EFFECTIVENESS: WHAT THE RESEARCH TELLS US," Sloan Center for Online Education, vol. 4, pp. 106-116, 2003.

[13] E. D. Wagner, "Interactivity: From Agents to Outcomes," New Directions for Teaching \& Learning, vol. 1997, pp. 19-26, 1997.

[14] R. B. Marks, S. D. Sibley and J. B. Arbaugh, "A Structural Equation Model of Predictors for Effective Online Learning.," Journal of Management Education, vol. 29, pp. 531-563, 2005.

[15] C. Sierra, "Building a Dynamic Online Learning Community among Adult Learners," Educational Media International, vol. 40, pp. 49-62, 2003.

[16] J. B. Arbaugh, "How Classroom Environment and Student Engagement Affect Learning in Internet-based MBA Courses.," Business Communication Quarterly, vol. 63, pp. 9-26, 2000.

[17] K. Swan, "LEARNING EFFECTIVENESS: WHAT THE RESEARCH TELLS US," Sloan Center for Online Education, vol. 4, pp. 106-116, 2003.

[18] J. K. Eastman and C. O. Swift, "New Horizons in Distance Education: The Online Learner-Centered Marketing Class," Journal of Marketing Education, vol. 23, pp. 25-34, 2001.

[19] P. Sullivan, "GENDER DIFFERENCES AND THE ONLINE CLASSROOM: MALE AND FEMALE COLLEGE STUDENTS EVALUATE THEIR EXPERIENCES," Community College Journal of Research \& Practice, vol. 25, pp. 805-818, 2001.

[20] G. Arthur, "Net gain: expanding market through virtual communities," 1997.

[21] L. M. Harasim, Online Education: Perspectives on a New Environment: Greenwood Publishing Group Inc., 1990.

[22] C. N. Gunawardena, C. Lowe and T. Anderson, "Interaction analysis of a global online debate and the development of a constructivist interaction analysis model for computer conferencing," Journal of Educational Computing Research, vol. 17, pp. 395-429, 1997.

[23] J. Wolfe, "Gender, Ethnicity, and Classroom Discourse: Communication Patterns of Hispanic and White Students in Networked Classrooms.," Written Communication, vol. 17, pp. 491519, 2000.

[24] J. L. Whipp and H. Schweizer, "Meeting Psychological Needs in Web-based Courses for Teachers," Journal of Computing in Teacher Education, vol. 17, pp. 26-31, 2000.

[25] Y. Yoo, P. Kanawattanachai and A. Citurs, "Forging into the Wired Wilderness: A Case Study of a Technology-Mediated Distributed Discussion-Based Class.," Journal of Management Education, vol. 26, pp. 139-163, 2002.

[26] D. Jonassen, M. Davidson, M. Collins, J. Campbell, and B. B. Haag, "Constructivism and computer - mediated communication in distance education," American Journal of Distance Education, vol. 9, pp. 7-26, 1995.

[27] D. J. Davis, "Developing text for web-based instruction," HANDBOOK OF DISTANCE, p. 287, 2003.

[28] R. Benbunan-Fich, H. R. Lozada, S. Pirog, J. Wisenblit, and R. Priluck, "Integrating Information Technology into the Marketing Curriculum: A Pragmatic Paradigm," Journal of Marketing Education, vol. 23, pp. 5-15, 2001.

[29] K. R. Lang and J. Leonzhao, "The Role of Electronic Commerce in the Transformation of Distance Education," Journal of Organizational Computing, vol. 10, pp. 103-127, 2000.

[30] L. J. Smith, "Content and Delivery: A Comparison and Contrast of Electronic and Traditional MBA Marketing Planning Courses," Journal of Marketing Education, vol. 23, pp. 35-44, 2001.

[31] R. V. Kozinets, "E-tribalized marketing?: the strategic implications of virtual communities of consumption," European Management Journal, vol. 17 , pp. 252-264, 1999.
[32] W. Drago, J. Peltier and D. Sorensen, "Course content or the instructor: which is more important in on-line teaching?" Management Research News, vol. 25, pp. 69-83, 2002.

[33] R. Ballantyne, J. Borthwick and J. Packer, "Beyond Student Evaluation of Teaching: Identifying and addressing academic staff development needs," Assessment \& Evaluation in Higher Education, vol. 25, pp. 221-236, 2000.

[34] J. W. Peltier, J. A. Schibrowsky and W. Drago, "The Interdependence of the Factors Influencing the Perceived Quality of the Online Learning Experience: A Causal Model.," Journal of Marketing Education, vol. 29, pp. 140-153, 2007. 